\title{
Shareholders General Assembly's Authority over the Auditor
}

\author{
Dr. Mahmoud Mohamed Elyan Al-Shawabka \\ Assistant Professor \\ Commercial Law \\ Faculty of Law \\ Al-Isra University, Amman, Jordan
}

\begin{abstract}
The problems that companies suffered and are still suffering, including the joint-stock companies that result from poor management and/ or corruption highlighted the matter of tightening control over the works of joint-stock companies that, as a rule, are key competences of the shareholders of those companies. However, whereas their assumption of this duty directly is different in the practical terms, the various legislations tended to assign that duty to what is now called "auditor". This reflects the important role assumed by the auditor for protection of shareholders; since auditor is the entity assigned to control of the company's financial management works. From this standpoint, it is important to determine the General Assembly's authority over the auditors, and the duties assigned to the auditor as well as his responsibility in confrontation of them, because of the direct effect of this approach in refining the company's board works, and to achieve the idea of rational management of the company. Consequently, this study handled the general assembly's authority over the auditor; it highlight in the first topic the sides related to appointment and termination of auditor. The second topic highlighted the duties assigned to the auditor and his responsibility before this assembly. The study drew set of conclusions that were followed by number of recommendations. We believe that adoption of those recommendations will refine the board works of joint-stock companies. This inures to the benefit not only of the company's shareholders, but to the benefit all customers and to the national economy as a whole.
\end{abstract}

\section{Introduction}

Under the so-called basic rights of shareholder, those rights that may not be compromised or prejudiced, the shareholder's right to management, which is one of the key and most fundamental rights, is achieved by supervision and control over the company by shareholders. However, in view of the difficult practice by all shareholders of this right directly, because of their big number, and the separation between the company and general shareholders ${ }^{(1)}$, in addition to the fact that most of them don't have the required capacity and necessary knowledge of the technical and accounting sides of the company, it was turned- under those conditions- to creation of practical solutions through which this authority was vested in many authorities in the company. Some assume execution and others assume control and supervision. This enables the company to achieve the purpose for which the company was established. Those authorities are: general assembly, ordinary and extraordinary general meeting, board and auditors, along with the role assumed by the state under the idea of management for the sake of protection of the general shareholders from which the nature of this company has become far from attention to practice of their right to control over the company, and supervision of them, in addition to the effect of those companies on the national economy to assume the large economic projects.

Concerning the auditor, it is commonly known that the duty assigned to him is to control the works of financial department of the company. It is a duty in the core competence of the company's shareholders. However, whereas assumption of this duty by themselves is difficult in the practical terms, the various legislation tended to assign this duty to the so-called: auditors, which highlights the role assumed the auditors in protection of shareholders as entity to which they assigned the duty of control of the company's financial works. It is important to determine the general assembly's authority over the auditor and the duties assigned to auditor and liability that may arise out of same.

\footnotetext{
${ }^{(1)}$ For further discussion of reasons between them that cause the shareholder's separation from the company, see: Abu ZaydRadwan, Dr. HossamEissa, joint-stock companies and public sector, Dar Al-Fekr Al-Araby, Cairo, 1976, Cairo, 1976, pp. 11-13. 


\section{Importance of the study:}

The importance of this study stems from the problems that joint-stock companies suffered, and still suffer, as a result of poor management and/ or their corruption, which gives rise to the importance of tightening control over the works of joint-stock companies. Whereas this duty is in the core of competence of shareholders of those companies, and their assumption of this duty by themselves in difficult in the practical terms, the various legislations assigned this duty to the so-called auditor, which highlights the importance role assumed by the auditor in protection of shareholders, as an entity assigned to the duty of control over the works of financial management of the company. Therefore, it is important to determine the general assembly's authority over the auditor, the duties assigned to him and responsibility to be assumed by him, in confrontation of this problem, because of its direct effect on refining the company's board works and force achievement of the idea of rational management of the company.

\section{Limitations of the study}

This study is limited to investigation of the general assembly's authority over auditors in terms of appointment and dismissal of auditor and auditor's duties. The study will look into the civil liability of auditor all in confrontation of the general assembly of shareholders. We will not exceed this to penal liability.

\section{Methodology of the study}

The approach of this study depends on two methodologies: descriptive and comparative methodologies. This methodology handles the legal texts and the rules of governance of companies related to the matter of the research by study and examination to determine the legislator's intention of legislation, and to determine the deficits and strengths and express the point of view in this respect.

\section{Plan of the study}

The pillars of this study are divided into two topics as follows:

First Topic: Authority of general assembly in appointment and dismissal of auditors.

First Theme: Appointment of auditor

Second theme: termination of auditor

Second topic: Auditor's duties to the shareholders' general assembly

First theme: auditor's duties

Second theme: general assembly's authority to file the case of liability against the auditor

\section{Shareholders General assembly's authority over the auditor}

The shareholders' general assembly shall be assigned to the duty of control of the company's financial management works. Whereas their assignment of this duty directly is difficult in the practical terms, various legislations tended to assign that duty to what is now called "auditor". This reflects the important role assumed by the auditor for protection of shareholders; since auditor is the entity assigned to control of the company's financial management works. From this standpoint, it is important to determine the General Assembly's authority over the auditors, and the duties assigned to the auditor which is the matter that will be discussed by the study in two topics as follows:

First topic: General Assembly's authority in appointment and dismissal of auditor.

Second topic: Auditor's duties to the general assembly of shareholders.

\section{First topic}

General assembly's authority o appointment and dismissal of auditor

It is important to identify the nature of relation between the general assembly of shareholders and auditors of the company, which is a must for study to determine the method of appointment and the method of appointment. This will be discussed in two topics. We will allocate the first topic to discuss appointment of auditors, while we will dedicate the second theme to define the sides related to dismissal of auditor.

\section{First topic}

\section{Appointment of auditor}

The shareholders' general assembly's exclusion of supreme authority in the company is reflected in that chooses the company's board and choice of auditors, which is stated by the Jordanian legislation in article (192/1) of the companies' law as authentic jurisdiction thereof, taking into account the transfer of this capacity, by exception, to the general auditor of companies, if it the general assembly couldn't elect him for whatever, 
or when the auditor elected by the assembly can't undertake his work or in case of death. The companies' Controller shall choose the auditor in such cases out of three auditors to be instructed to the auditor by the company's board, in accordance with article (192/2).

In the same respect, we find that the Egyptian legislation detailed this matter. Even though the general assembly is assigned, in accordance with article (103) of the Egyptian companies' act, as the party that has the original right to choice of auditor, it had different view, as well, when it stated in the same article: "... It the company doesn't have, at any time and for whatever reason, auditor, the board shall take the measures of appointment of auditor immediately, and this shall be referred to the general assembly in its first meeting..." Therefore, even if the board is required to refer the matter to the general assembly of shareholders in its first meeting, it adopted more negative stance than that of the Jordanian legislature in this respect, when it assigned the board to the duty of choice of auditor, and it would have been better for the board not to be assigned by whatever means to the duty of choice of auditor $^{(2)}$.

In this respect, the study finds that legislature left room for appointment of auditor in the cases provided in paragraph two of article (192). Accordingly, it is wrong situation, because appointment of auditor by the board increases favouritism to him and narrows the scope in choice of auditor, according to the general rule, by the shareholders' general assembly. Consequently, we call legislator to perceive that there is stipulation either to invite the general assembly to meeting to choose new auditor or to follow the French legislature ${ }^{(3)}$, in this respect, because French legislature allowed any of the company's shareholders ${ }^{(4)}$ to require the court of jurisdiction to take, summarily, the procedures required for appointment of auditor, and emphasized, again, the necessity that Jordanian legislature perceives this matter. Unfortunately, Jordanian legislature didn't consider this case in its last amendment of 2017, as it retained this case as it is.

Turning to the conditions to be met by auditor, we find that whereas the auditor is accountant specialized in auditing the accounts of the company, and the purpose of appointment of auditor is to tighten control over the board works, the Jordanian legislature stipulated set of conditions to be satisfied by the auditor. The auditor shall first be licensed to practice the profession. Afterwards, to guarantee neutrality, honesty and independence of auditor, auditor shall not be founder, director or employee of the company because this would make the auditor's assumption of his duties neutrally, honestly and independently difficult, whenever the auditor has private interest in the company ${ }^{(5)}$. From this standpoint, we find that the French legislature prohibited, in accordance with article 222 of the companies' act of 1966, as amended in 1984, that auditor shall be founder of the country, holder of kind shares, or board member. In addition, French legislature prohibited auditor to be one of the relatives of any of the above persons up to the fourth degree. It prohibited that auditor be director or board member of the companies that own one tenth the capital of the company to be audited. Article 221 of the companies' act itself prohibited auditor from becoming board member or director of the company of which he was auditor for five years after the end of his work ${ }^{(6)}$.

By reference to the situation of Jordanian legislature, in addition to the foregoing, the auditor shall satisfy the conditions stipulated in article (17) of the instructions of disclosure and accounting standards issued by the board of trustees of the Securities Authority as follows: Auditor shall be holder of valid professional license from the auditing board. He shall be member of the Jordanian Chartered Auditors' Association, and shall be classified in category (A) in accordance with the applicable auditors' classification regulation.

(2) For further information on this topic: Judge RagabSelim, explanation of the companies' act, $3^{\text {rd }}$ edition, Bala Publishing House, Cairo, 2004, p. 1190, Dr. Samiha Al-Qalyoubi, Commercial Companies, Dar Al Nahda Al Arabiya, Cairo, $3^{\text {rd }}$ edition, 1993, p. 499, Fady Mohamed Tawakkal, External Control over the protection of shareholders in joinst-stock companies, master thesis, Faculty of Law, Cairo University, 2013, pp. 228-233.

(3) Article (324) of the French Companies' Law, 1966, as amended by article 187 of the decree of 23/03/1967. For further information, see: G. Rebier and R. Rebelo, Procrastination in commercial law, Part I, Commercial Companies, Al Halaby Law publications, $1^{\text {st }}$ edition, Beirut, 2008, p. 663, Dr. Elias Nassif, Commercial Companies, Part I, Al Halaby Law Publications, $1^{\text {st }}$ edition, Beirut, 2017, pp. 460, 460.

(4) TRD. COM. Avril - juin 2005, p358in published judgment, Dec, 2005,Paris 15.

(5)For further information, see Dr. Aziz Al-Akily, Al-Wassit in Commercial Companies, Dar Al Thaqafa Publishing and Distribution, Amman, $3^{\text {rd }}$ edition, 2012, pp. 325-327, Dr. Fawzy Mohamed Samy, Commercial Companies, Dar Al-Thaqafa Publishing and Distribution, $7^{\text {th }}$ edition, 2014, pp. 506-507.

(6) For further information on this, see Rebier, R. Rebelo, ibid, pp. 664-666.

70 
He shall have practiced the profession on full time basis for at least three consecutive years after obtaining the professional license. Finally, one or more auditors of those who satisfy the precedent conditions shall share him or work with him in his office ${ }^{(7)}$.

Concerning the number of auditors, we find that French legislature required the general assembly of shareholders to choose at least two auditors, in addition to choice of substitute auditor, to replace any of the auditors whose work expired prematurely for whatever reason, in accordance with the amended law of 1984. Concerning the Jordanian legislature, even though it was positive, Jordanian legislature didn't define t heir number. Jordanian legislature stated in article (192/A) that: "The general assembly shall elect one or more auditors". This allows the company to appoint more than one auditor. It would have been better to state that the joint-stock company has more than one auditor. This will guarantee to large extent that the company doesn't enter the phase of vacancy in case of occurrence of the above cases. Finally, concerning the auditor's fees, in view of the fact that the general assembly of shareholders is the entity that originally appoints the auditor, it is the entity that shall define his fees. It is not possible for the general assembly of shareholders to authorize the board to choose auditor of the company. However, if there is nothing to prevent that general assembly from authorizing the board to define the auditor's fees. Even though the Jordanian legislature didn't restrict that power granted to the board by any ceilings to be established by the general assembly, the Egyptian legislature stipulated that the general assembly of shareholders define those fees ${ }^{(8)}$. It shall be stated that the Egyptian and Jordanian legislatures would have better not allowed the board to define the auditors' fees. That criticism is not undermined, for the Egyptian legislature ${ }^{(9)}$, that it restricted the board with the maximum limit that the general assembly of shareholders shall establish, because the board's determination of the auditor's fees is undoubtedly breach of the principal of independence between the auditor and board, and constitutes real threat to the control role endowed to the auditors, so how can we guarantee that the auditor doesn't favour the board whenever it is the board that defines the auditor's fees.

\section{Second theme}

Completion of the auditor's duty

It has become commonly known that the general assembly of shareholders has the authentic competence to appoint the company's auditor- for one year- and that the assembly, afterwards, shall have the competence to dismiss him, whenever the auditor commits any of the acts that justify same, or whenever the assembly finds that he didn't duly discharge the works assigned to him.

The auditor's work shall in general end by occurrence of many reasons. First: Expiry of the term defined for the auditor to discharge his duty. Second: Resignation or excuse of the auditor to discharge the duties of auditing. Third, dismissal of auditor by the general assembly of shareholders ${ }^{(10)}$.

Whereas the period of work of auditor is one year, it is normal that his work be completed by expiration of this period, unless that duty is renewed by the general assembly for one year ${ }^{(11)}$. Legislature authorized the general assembly of shareholders to renew the auditor's work after expiry of the period for which the auditor is appointed, which is one year. In view of the fact that legislature didn't define the number of times of renewal of the auditor's work, and for the sake of guarantee of the auditor's independence from the company's board and neutrality in the work that he performs and the reports that he presents, the study requires adoption of its arguments in this respect, concerning the controlling rules in this respect, and the rules of governance of joint-stock companies listed in

Amman Stock Exchange ${ }^{(12)}$. Number of times of renewal shall be defined.Concerning the auditor's apology for discharging his duties in the company, which is the second reason for termination of his work, whereas it is the right of auditor to inspect at any time the books, records and documents of the company, in addition to the auditor's right to request any of the data that the auditor finds necessary to access.

(7) For further information on this, see Dr. Aziz Al-Akily, ibid, pp. 325-326.

(8) For further information about this, see Rebier, R. Rebelo, ibid, pp. 668-669, Dr. Samiha Al-Kalyouby, Ibid, p. 489, Judge RagabSelim, ibid, p. 1212.

(9)See rules of governance of Egyptian companies, section 7/5.

(10) On the situation of French legislation in this respect, see Rebier, R. Rebelo, ibid, pp. 670-672.

(11)Article (192/A) of the Jordanian companies' act stated that: "The general assembly shall elect for each of the joint-stock company and ........... one or more auditors authorized to practice the profession for one renewable year..."

(12) Section five of chapter four of the rules of governance of joint-stock companies listed in the stock exchange for the year 2008. 
The auditor shall have the right to verify the assets and liabilities of the company ${ }^{(13)}$. Whereas the Jordanian legislature entitled the auditor to the right to apologize for auditing the company's accounts whenever there is prohibition against his performance of this or anything that would prevent the auditor from performing all his duties. Article (194) of the companies' act states that the auditor shall have the right to apologize for auditing the company's accounts whenever the auditor faces obstacles or obstructions that would prevent the auditor from discharging the works assigned to the auditor, provided the auditor presents to the company written report of which copy shall be sent to the board. In that report, the auditor shall define the reasons that obstruct its work or prevent the auditor from undertaking his works. This requires the general auditor of the company to manage the reasons provided in the auditor's report with the board. If those reasons are not managed, the auditor shall refer the matter to the general assembly of the company in its first meeting to take the reasonable decision in this respect. Before turning to discussion of the third and last reason of the auditor's termination, we shall confirm that if the Jordanian companies' legislature didn't handle the option of auditor's resignation, the auditor's right to resign, in accordance with the general rules, shall be taken into account, provided the company is notified therewith sufficient time in advance. The company shall exceptionally appoint new auditor who shall be required to continue in his work for reasonable period of time till the new auditor is appointed in accordance with the legal required set forth in article (192/B) of the companies' act. Whereas the auditor's relation with the company is governed by the rules of his proxy, the auditor shall not normally abuse this right. Therefore, the auditor shall be required to choose the reasonable time for resignation. Otherwise, the auditor shall be required to indemnity the company for the damages that the auditor sustains as a result of this resignation ${ }^{(14)}$.

Turning to the third reason of termination of the auditor's work being dismissal of auditor by the general assembly of shareholders, we shall assure the right of the general assembly of shareholders to dismiss the auditor as proxy of the company ${ }^{(15)}$ in this respect, as a result of the auditor's mistakes or when there is prohibition against the auditor's performance of the duties assigned to him $^{(16)}$.

(13) For further information on this see: Dr. Aziz Al-Akily, Al Wassit in commercial companies, Dar Al Thaqafa Publishing and Distribution, Amman, 2012, p. 331.

(14) For further information on this, see the bulletin of the Auditors' Union, France, 1968, see Rebier, R. Rebelo, ibid, pp. 664-666, ibid, p.672.

(15) He is not proxy of shareholders. This was expressed by the Jordanian legislature in article (199/A) of the companies' law. In this respect, we state that since it is proved that to say that (A) authorizes (B) in certain matter means that each of them shall have the legal character. Whereas the general assembly of shareholders doesn't have the corporate legal person, it is not possible, by law, to state that: "The general assembly of shareholders shall authorize the auditor". If it is known that the general assembly of shareholders is the entity that appoints the auditor, this is because the general assembly is the source of authorities in the company and it shall have the upper authority therein, so that the auditor be proxy, not of the general assembly of shareholders, but for the company, because the general assembly of shareholders doesn't have, as mentioned before, the corporate legal person. Therefore, in spite of the error committed by the Jordanian legislature in this respect, it didn't mean to violate the basic rules of law in this field. However, we shall state that if the general assembly of shareholder is the entity that appoints auditor, legislature can't state that the auditor is proxy thereof, because when the general assembly does this, as indicated before, it shall do this as the party that has the upper authority in the company and that expresses its will in this respect. Therefore, we call legislature to reform this matter in the draft companies' act that government tends to refer to parliament, and to express the case by the reasonable expressions. We have to note here that the expression given by Dr. Al Akily in section 215, p. 335 of the aforementioned book, is that he is: "proxy of shareholders" that was criticized by Dr.AkramYamelky in his book titled ............. which provided in the context of its explanation of the situation of Jordanian legislature that considered the auditor as proxy of the company. Dr. Al Akily didn't mention any violation of this framing or even reservation of them. This is by nature completely different from the argument of some, including the nature of this nature, represented in consideration of auditor as proxy of the company. We find that Dr. Mohamed Farid Al Ariny says- in the abovementioned book: "In contrast to the view of some, the Controller shall not be proxy of shareholders." Here we refer to (Rodier) and add that we are in the situation of Jordanian legislature, as proxy of the company- in article 106 of the companies' act of 1981. Dr. Al-Ariny continues to present his opinion that auditor is not proxy of shareholders, and bases his opinion on the statement that "He shall not be assigned to enter into legal disposals." The text of law to dismiss the auditor in all cases in contrast to the paid proxy is flawed, because it puts the auditor under the mercy of the board that controls in most cases the general assembly. This means that he is independent in his work. Dr. Al-Ariny embodies his situation by stating that: "The controller is in fact one of the assets of the legal structure of the company and shall be assigned to control of its accounts". Dr. Al Ariny refers to G. Rebier, Rebelo, Mustafa Taha and Abu ZaydRadwan. Dr. Al Ariny continues to present his opinion by stating that: 
Decision of dismissal shall be issued by the general assembly of shareholders in its meeting to be held upon invitation to be forwarded by the company's board, either automatically or upon request of shareholders ${ }^{(17)}$. Discussion of this right requires highlight of some liabilities of the auditor, particularly those defined by legislature the denial of which shall be basis for the general assembly on taking any decision of dismissal. Legislature mentioned in articles (202) and (203) of the Jordanian companies' act some acts that justify for the general assembly to dismiss the auditor. We find that article (202) prohibited auditor from disclosing to shareholders, whether in the venue of meeting of the general assembly of the company or elsewhere, to shareholders or to others the company's secrets that it may have accessed in the occasion of his performance of his work. Article (203) required the auditor and his personnel not to speculate with shares in the company, either directly or indirectly. If the auditor violated any of those obligations, the auditor shall be dismissed and required to pay compensation ${ }^{(18)}$.

If the auditor's violation as indicated above undoubtedly requires his dismissal and claim to pay compensation, what doesn't require conformation is that the reasons that give rise to dismissal of auditor and asking him to pay compensation are not limited to breach of those obligations that were defined by legislature in those two articles, because, even though the auditor isproxy of the company ${ }^{(19)}$, the responsibility that he assumes in accordance with this legal framing, which covers any mistake or failure by auditor in the auditor's performance of the works assigned to the auditor, shall entitle the general assembly of shareholders to dismiss him and claim compensation accordingly ${ }^{(20)}$, taking into account that there is no doubt that the general assembly of shareholders shall have the right to dismiss the auditor at any time and for whatever reason. There is no doubt that the assembly shall not abuse this right. If the auditor who was dismissed proved that the general assembly abused this right, the assembly shall be bound to compensate the auditor for the damage caused to the auditor in accordance with the ruling of the court that considers this matter. It shall be intuitive to say that issuance of decision of dismissal of auditor by the general assembly results in termination of the contractual relation between the auditor and the company, so it is not possible in this point for the auditor to exercise any of the works of control in the company.

\section{Second Topic}

Auditor's duties and liability towards the general assembly of shareholders

The company's auditor shall assume set of duties that the auditor shall, on discharge of them, make the diligence required by legislature that, if violated by the auditor and caused damage to the company, it is normal at this point to hold the auditor liable to the company. Therefore, the study will handle the auditor's duties to the general assembly and the auditor's liability to it, in two themes. The first theme assumes the auditor's duties, while the auditor's duties to the general assembly shall be handled in the second theme.

\footnotetext{
"Even if auditor is elected by shareholders, he shall not lose his independence against them, or against the board, which called some to call him the judge of numbers. The other person who was mentioned is Bloch-Laine". For further information, see Dr. Mohamed Farid Al-Ariny, ibid, p. 463.

(16)The error means here failure of execution or bad execution of the duty assigned to him as a result reason attributed to him. The legal prohibition means the violation that may be committed for the cases of prohibition, such as: To be founder of the company or to provide kind share in its capital. We find that material prohibition means what would inflict the auditor which would make him unable to perform his duties, as when he is inflicted with disease that make him stay in bed. See article (227) of the French companies. In this respect, Dr. Mohamed Farid Al-Ariny referred to commercial law, ibid, p. 455, in margin No (3).

(17) Dr. Al Akily, ibid, p. 340. In this respect, we find that Egyptian legislature, for guarantee of neutrality and independence of auditor, established specific measures on dismissal of him, including order to the shareholder to propose the change of auditor by notifying the company with his desire and the reasons on which he relies, sufficient time before the general meeting in which case the company shall notify the auditor with this suggestion and the reasons for it.

(18) For further information on this, see Dr. AkramYamelky, commercial law, commercial companies, Dar Al Thaqafa for Publishing and Distribution, Amman, $3^{\text {rd }}, 2010,311$.

(19) Article (199/A) of the Jordanian Companies' act, 1997.Dr. Samiha Al Kalyoubi, ibid, p. 496.

(20) Concerning those mistakes that give rise to Controller's liability, see article (201) of the Jordanian Companies' act of 1997. For further information on this, see: Dr. AkramYamelky, ibid, pp. 311-315.
} 


\section{First theme}

\section{Auditor's duties}

The auditor's duties in the company shall be defined in controlling and auditing its accounts in the year for which the auditor is appointed. The auditor shall assume, within this timeframe, the duty of auditing the company's works and auditing the company's accounts in general. In accordance with the requirements of article (193) of the companies' act, the auditor shall, in particular, control the company's works and audit its accounts in accordance with the generally acceptable rules and practices of auditing, and shall disclose the financial and administrative regulations of the company and the internal financial control systems, and shall assure the safe progress of works of the company to define the success of those regulations in keeping the company's money. The auditor shall verify the company' assets and real ownership of them. He shall also assure the validity of the company's liabilities and obligations. It is necessary to assure in this respect that the auditor's control authority doesn't extend, under any circumstances, to intervention in the board works or control over the suitability of his decisions. The auditor's duty in this respect shall not exceed the limits of observation and monitoring of the mistakes and violations that may be committed, and to collect the information related thereto. The auditor shall advise the board with such errors and violations and advise the general assembly of shareholders later, if they are not removed and repaired $^{(21)}$.

To enable the auditor to perform the works assigned to the auditor, we find that legislature required the auditor, in accordance with the text of the mentioned article required the auditor to access the board decisions and the instructions issued by the company, and any other data required to be obtained and assured by auditor for the nature of his work ${ }^{(22)}$. Whereas the auditor's access to the mentioned data is normally required by the nature of the duty assigned to the auditor, we note that legislature included in article (193) titled: "Auditor's duties", so the auditor doesn't have the right. This confirms that the auditor shall assume this duty, because the person may not be blamed if he didn't use the rights created to the person by law while he shall be blamed without doubt if he didn't assume his duties in accordance with law. Therefore, there is difference between the two terms. We find that the Jordanian legislature was successful in this respect, in contrast to the Egyptian and French legislations that used the expression "right" of auditor to access the company's details, including the records, books and documents when they regulated this duty in article (228) of the French companies' act, and article (105) of the Egyptian companies' act. The Egyptian legislature stated that: "Auditor shall have the right at all times to access the company's books, records and documents.... The article"

The Jordanian legislature expanded, in accordance with article (193) as well, the auditor's duties to include, in accordance with the foregoing, any duties to be imposed on the auditor in accordance with the companies' act and the auditing law and other related laws. Finally, legislature required, in accordance with article $(193 / G)$ of the companies' act, that the auditor prepares written report to be presented to the general assembly of shareholders and to be recited by the auditor or any person that may be appointed by the auditor before the general assembly of shareholders. Legislature stated in article (195/A) of the companies' act five paragraphs in which it listed the contents of this report, primarily: that it has obtained the information, data and notes that he find to be necessary for performance of his work. Second, that the company keeps regular accounts, records and documents, and that the financial statements of the company were prepared in accordance with the generally acceptable accounting auditing standards to guarantee that the company's financial, results of works and cash flows are properly presented, and that the budget and statement of profits and losses are in agreement with the company's entries and books.

(21) For further information on this, see Dr. Abu Zayd, Joint-Stock Company, Dar Al Fekr Al Araby, Cairo, 1983, Fady Mohamed Tawakkal, ibid, p. 275 onwards, ZeinabRefaat Sayed, Obligation of notification in the joint-stock companies, Faculty of Law, Ain Shams University, 2015, pp. 173-176.

(22) For further information, see Dr. Khaled Ramadan, Criminal Liability of Auditor and Chartered Accoundant, Comparaive Study, Dar Al Nahda Al Arabia, Cairo, 2008, p. 92, Dr. Abu ZaydRadwan 267, ibid, pp. 267 and 268, Dr. Samiha Al-Kalyoubi, ibid, p. 492, Dr. Fawzy Mohamed Samy, Commercial Companies, General and Special Rules, Amman, $8^{\text {th }}$ edition, pp. 507-509, Dr. Samy Al-Kharabsha, ibid, pp. 222-223. 
Paragraph three ${ }^{(23)}$ of the same article states that the auditor's report shall state that the auditing procedures done by the auditor for the company's account are, in the auditor's opinion, sufficient to be reasonable basis for the expert to express his opinion, in accordance with the report, on the financial position of the company and its business outcomes and cash flows in accordance with the generally acceptable auditing rules.Paragraph four of the mentioned article required that the report states that the financial data contained in the board report to the general assembly are consistent with the entries and records of the company.

Finally, paragraph five of the mentioned article confirmed that the mentioned report submitted to the general assembly of shareholders the violations of law or law of the company during the year under auditing which has essential effect on the outcomes of the company's works or financial position, and shall state whether those violations still exist, all in accordance with the information at hand or the information that he shall possess.

The auditor shall, in accordance with article (195/B) of the companies' act, shall express his final opinion on the balance sheet, profit and loss account and options in this respect- in accordance with this article- which are, either to ratify them or the cash flows of the company, without reservation; that is, absolutely, or with reservation, provided this is because of this reservation or its effect on the financial terms of the company is mentioned, and to ratify them or return it to the board with the necessity of reasoning this refusal.

In addition, to enable the auditor to discharge the requirements of the project, the board of the company shall enable the auditor to get the data required by the company. If the auditor is not enabled, the auditor shall, in accordance with article (194) of the companies' act, record this in report to be presented in writing to the General Controller of Companies, to reckon the reasons that impede the progress of his work or prevent his performance of the works assigned to him. The auditor shall settle those reasons with the board. If it is difficult for the auditor to do this, the auditor shall in this case refer the matter to the general assembly of shareholders in its first meeting. The importance of this arises in handling the criminal liability of the auditor, because the auditor shall not liable for it unless the auditor is enabled to access the data required to properly make his report ${ }^{(24)}$.

To enable the auditor to assure the validity of the measures of invitation to the general assembly meeting, legislature required the board of the company, in accordance with article (198) of the companies' act, to provide the auditor with copy of the reports and data to be sent to the shareholders' board which include, by nature, invitation to the assembly meeting.

\section{Second theme}

\section{General assembly's authority to file case of liability against the auditor}

In accordance with article (201) of the Jordanian companies' act, Jordanian legislature stated that auditor shall be held liable to the company, its shareholders and third parties. Whereas legislature decided this matter, as indicated before, and considered the auditor to be proxy of the company, not as member in "its body", the basis of liability in relation between the auditor and the company is the contract whereby the auditor has become, proxy of the company, we find that the basis of this liability in relation between the auditor and shareholders and the third parties is tort.

The auditor's liability to the company shall be determined in light of the general rules of paid proxy, in addition to the legal provisions contained in the companies' act, and the law of professional practice of the auditor, and the law of Securities Authority as well as the instructions made in accordance therewith.

Concerning the general rules, whereas the auditor assumes his work for payment to be defined by the general assembly of the company, in accordance with article (192/A) of the companies' law, whether directly or through the board, upon the company's authorization to him, his liability for those works shall be defined in accordance with the rules of paid proxy, as defined in article (841/2) of the civil law according to which the auditor shall use for its purpose what is assigned to the auditor, the due diligence to be liable, when assuming his duties, for the mistake, omission or default that may be committed by him.

(23) The study records here note on the drafting of article (195/A) of the companies' law in general, and paragraph three of its five paragraphs, which states that: "The auditing procedures done for the company's accounts shall be sufficient in his opinion to be reasonable basis for expression of his opinion the company's financial position, business outcomes and cash flows of the company in accordance with the generally acceptable auditing rules". We find that this article is a clear example of "poor drafting". Legislature in this respect shall not be in the process of establishing the legal rules.

(24) For information on this, see: Fady Mohamed Tawakkal, ibid, pp. 275-276. 
According to the companies' act, we find that- jointly with the general rules- held auditor liable to the company and its shareholders, in addition to the auditor's liability to any third party who relies, in good faith, on its financial statements on his disposal or purchase of its shares, to be liable for execution of his work and shall indemnity the damage he caused or the profit he lost.

Concerning the relation between the auditor and the company, the relation between them is contractual relation based on the agency agreement concluded between them. Even though the Jordanian legislature stated, through article (199/1) of the companies' law, states that auditor "proxy of shareholders", and whereas the study criticizedin previous position- this expression, because the auditor is proxy of the company not proxy of the general assembly of shareholders, this proves that Jordanian legislature followed this view due to the fact that the general assembly of shareholders shall have the upper authority in the company. This confirms that legislature separates the company from its shareholders. Legislature reckoned, in article (201) of the companies' law, the entities before which the auditor shall be liable, mentioned: the company and its shareholders. Therefore, the entity, which is the company, and the other, the shareholders, before which the auditor shall be liable. Therefore, there are two "different" entities in terms of law. They first entity- the company- shall be liable with the auditor in contractual relation. If it is right to say that the board represents the company, we shall say as well that the board is only proxy of the company elected by the general assembly of shareholders, as is the case for the auditor. Therefore, if the board has the right to file the case of liability for auditor, on behalf of the company, there is no doubt that it is the right of the general assembly to file the case of liability against the auditor as "Principal" who shall have the higher authority in the company.

Concerning the relation between the auditor and shareholders, who are the second entity, received from the three authorities mentioned by legislature in the mentioned article, the auditor's liability for the damage sustained by shareholder is tort the basis of which is the error committed in his performance of the work assigned to him, which caused to damage to them since the contract of the auditor is contract between the auditor and the company, not between the auditor and "shareholders individually" ${ }^{(25)}$.

To hold the auditor liable, we shall prove that there is error, default or neglect on the part of the auditor, taking into account that if the auditor is required to make the diligence not to achieve purpose, the intended purpose here is the purpose required by the nature of work based on agency and the conditions to be satisfied by the auditor, which is the due diligence, which is expressed as "professional diligence"; that is, what is required from him, which is to follow "the due diligence" ${ }^{(26)}$; the auditor is expert and those who are like him shall assume his work, in accordance with the skill and experience required for this work, and to assume the process of auditing that shall be done by the auditor, in accordance with the generally acceptable international accounting standards ${ }^{(27)}$, taking into account that if the error committed is not sufficient for claim of compensation, because this damage results in error and that there is damage that happened because of this error.

It shall be noted here that the auditor's liability shall not be limited to the auditor's acts in terms of error, default or omission; it shall exceed this to include the error, default or omission that may be committed by its assistants, for the purpose of the general rules of liability of subordinates, in view of the authority of the subordinate (auditor) of the superordinate in control and counselling ${ }^{(28)}$.

(25) For further information, see: G. Rebier, R. Robelo, ibid, p. 681 onwards, Dr. Aziz Al-Akily, ibid, p. 336.

(26) In this respect, the study doesn't agree with the description that was provided by Dr. Mohamed Farid Al-Ariny in his book that was previously mentioned. This is expressed on page 464, and stated: "diligent auditor's behavior", because this expression wasn't accurate because if we took it for granted, we would state that there is diligent auditor and different auditor. This is standard used through the term: "Man". Whereas it is known that if the proxy is paid, the due diligence here means diligence of average man. It is normal to say here that: If the proxy is not paid, diligence required from him is: diligence in his money where the case is different. If he is diligent in his proxy, he shall not be liable on this basis, even if the average diligence in his own money or if he is neglectful, he shall not be liable for his execution of the proxy on this basis. Where the auditor is specialized expert, from the perspective of what shall be, not what may be, shall be "always" diligent. Therefore, use of the expression, "diligent auditor" can show that auditor may have average diligence or be neglectful. To measure on this basis, we shall use the expression or term "diligent man", which is the expression that shall be used.

(27) For further information, see Dr. Samiha Al Kalyoubi, ibid, p. 496, Dr. Ali Sayed Kassem, Auditor, Comparative study of the auditor's role in joint-stock company, Dar Al Fekr Al Araby, 1991, p. 119, Dr. Aziz Al Akily, ibid, p. 336.

(28) Article (288/1) of the Jordanian civil law. 


\section{Conclusion}

This study handled the matter of "Shareholders General Assembly's Authority over the Auditor" in two topics. In the first topic, the study highlighted the sides related to appointment of auditor and termination of his duties. The second topic of the research focused on the auditor's duties and liability to the assembly. This reflected the important role assumed by auditor in protection of shareholders since auditor is the person assigned to control over the financial management of the company. The importance of this study lies in determination of the general assembly's authority over the auditor, the duties assigned to him and the auditor's liability to the assembly, because of its direct effect on refining the works of the company's board and therefore achieve the idea of rational management of the company.

The study drew set of results that were followed by number of recommendations that we believe their adoption will refine the work of joint-stock company's board, which will inure to the benefit not only to the company's shareholders but also to the general customers and national economy as follows:

\section{Results}

The study indicates that the Jordanian legislature assigned the general assembly of shareholder as the entity that has the higher authority in the company to the duty of choice of auditors who shall use the regular man's diligence in discharge of their duties, which requires them to follow the international standards and international auditing standards according to the professional custom in the similar cases.

It has become clear that Jordanian legislature had negative attitude when it assigned the General Controller of Companies, as exception, the right to choose auditor out of three names to be instructed to the General Controller of Companies by the company's board, whenever the general assembly couldn't elect him for a reason or another, or on death or objection of auditor to discharge his work. The study also indicates that the Egyptian legislature went beyond the Jordanian legislature in this respect, when it assigned the board itself to choose auditor of the company in case the auditor's position is vacant, while the French legislature had successful attitude in this respect because, in addition to requiring the general assembly of shareholders to elect two auditors for the company, it required it as well to choose reserve auditor.

The study indicates that, as a general rule, it is the general assembly of shareholders that appoints the auditor and therefore, general rule, defines his fees. It has become clear that if it is not possible for the general assembly of shareholders to authorize the company's board to choose auditor of the company, there is nothing to prevent that assembly from authorizing the board to define the auditor's fees.

Moreover, the study indicates that it is the general assembly of shareholders that appoints, as a general rule, the auditor and, therefore, it is the entity that defines his fees, provided if it is not possible for the general assembly of shareholders to choose auditor of the company, the Jordanian legislature allowed the general assembly to authorize the board to the duty of defining the auditor's fees provided the minimum of this is defined by the general assembly.

\section{Recommendations}

The study wishes that the Jordanian legislature orders the general assembly to choose no less than two auditors of the company- as is the case for the French legislature- or, at least, that the Jordanian legislature orders the general assembly to choose reserve auditor if the Jordanian legislature found that one auditor suffices for this task.

The study wishes that the Jordanian legislature gives any of the company's shareholders, in case of vacancy of the position of auditor for whatever reason, the right to resort to the court of jurisdiction to assume the duty of choice of the company's auditor.

The study wishes that the Jordanian legislature orders the general assembly of shareholders to directly assume the definition of auditor in all cases to restrict the general assembly from assigning the board to the capacity of defining the auditor's fees because this constitutes breach of the principle of auditor's independence from the board.

\section{References}

\section{First: Books}

Abu ZaydRadwan, Dr. HossamEissa, Joint-Stock Companies and Public Sector, no publishing house, Cairo, 1976. 
Judge RagabSelim, Explanation of the Companies' Law, $3^{\text {rd }}$ edition, no publishing house, Cairo, 2004, p. 1190.

Dr.Samiha Al-Qalyoubi, Commercial Companies, Dar Al Nahda Al Arabiya, Cairo, $3^{\text {rd }}$ edition, 1993.

G. Rebier, R. Belo, "Encyclopedia of Commercial Law, Part I, Commercial Companies, Al-Halaby Law Publications, $1^{\text {st }}$ edition, Beirut, 2008."

Dr.Elyas Nassif, Commercial Companies, Part I, Al Halaby Law Publications, $1^{\text {st }}$ edition, Beirut, 2017, pp. 460461.

Dr. Aziz Al-Akily, Al Wassit in Commercial Companies, Dar Al Thaqafa Publishing \& Distribution, 3rd edition, 2012.

Dr.Fawzy Mohamed Samy, Commercial Companies, Dar Al Thaqafa Publishing and Distribution, Amman, 7th edition, 2014.

Dr.AkramYamelky, Commercial Law, Commercial Companies, Dar Al Thaqafa Publishing and Distribution, Amman, 3rd edition, 2010.

Dr. Abu ZaydRadwan, Joint-Stock Companies, Dar Al Fekr Al Araby, Cairo, 1983.

Dr. Ali Sayed Qassem, Auditor, Comparative Legal Study of the Auditor's Role in the joint-stock company, Dar Al Fekr Al Araby, 1991.

Dr. Khaled Ramadan, Criminal Liability of Auditor, Chartered Accountant, Comparative Study, Dar Al Nahda Al Arabia, Cairo, 2008.

\section{Second: Dissertations}

FadyTawakkal, Role of Auditors in Protection of Shareholders in Joint-Stock Companies, Dar Al Nahda Al Arabia, Cairo, 2013.

ZeinabRefaat Sayed, Liability in Media within the joint-stock companies, Faculty of Law, Ain Shams University, 2015. 